\title{
К развитию и расширению глинобитного строительства
}

\author{
Р.3.Рахимов, КазГАСУ, Казань \\ Н.Р.Рахимова, КазГАСУ, Казань
}

Глинобитное строительство и при этом поиски рационального использования повсеместно распространённых грунтов с древних времён и до настоящего времени являются эффективным направлением в решении современных проблем энерго-, реурсосбережения и экологии. В статье проанализированы мировой опыт глинобитного строительства с эпохи неолита до наших дней и описаны отдельные направления повышения физико-технических свойств грунтовых материалов. Показано, что в связи с ужесточением требований к ресурсо- и энергосбережению, экологической безопасности производства и применению строительных материалов во многих странах мира возрастает интерес к глиносырцовым материалам как к менее энергоёмким их разновидностям. Глинистые материалы нашли и находят применение в зданиях и сооружениях в виде: монолитных глинобетонных стен, перегородок и куполов; монолитных элементов слоистых стен и перегородок с облицовкой атмосферо-, водо-, износо-, ударостойкими материалами; сырцовых глинобетонных кирпичей и блоков для кладки стен, перегородок, печей и куполов; кладочных и штукатурных растворов; окрасочных составов. Приведены сведения о недостатках и достоинствах глин и материалов на их основе, добавках, улучшающих показатели физико-технических и эксплуатационных свойств материалов на основе грунтов, окрасочных составах глинобетонных изделий и глиняных отделочных покрытий. Приведённые в статье отдельные примеры мирового опыта являются ценной иллюстрацией возможностей развития и расширения глинобитного строительства, которые могут быть реализованы при возведении зданий и сооружений как сельскохозяйственного назначения, так и в гражданском, промышленном и жилищном строительстве.

Ключевые слова: глина, грунт, вяжущее, глинобетон, раствор.

\section{Towards Development and Expanding of Mudbrick} Building Construction

\section{R.Z.Rahimov, KSUAE, Kazan}

\section{N.R.Rahimova, KSUAE, Kazan}

Mudbrick construction and the search for rational use of ubiquitous soils from ancient times to the present are promising trends in solving modern problems of energy- and resourcesaving and ecology. The article analyzes the world experience of mudbrick construction from the Neolithic era to the present day and describes individual ways for improving the physical and technical properties of soil materials. It is shown that in connection with the tightening of requirements for resource and energy saving, environmental safety of production and use of building materials, in many countries of the world there is an increasing interest in clay raw materials as their less energyintensive varieties. Clay-based materials have found and are used in buildings and structures in the form of: monolithic clay-concrete walls, partitions and domes; monolithic elements of layered walls and partitions with cladding with weather-, water-, wear-, shock-resistant materials; raw clay bricks and blocks for laying walls, partitions, furnaces and domes; masonry and plaster mortars; paint compositions. The disadvantages and advantages of clays and materials based on them; additives that improve the physical, technical and operational properties of materials based on soils; painting compositions of clay-concrete products and clay finishing coatings are considered. The individual examples of world experience given in the article are a valuable illustration of the possibilities for the development and expansion of adobe construction, which can be realized in the construction of buildings and structures, both for agricultural purposes and in civil, industrial and residential construction.

Keywords: clay, soil, binder, clay-containing concrete, mortar.

\section{Введение}

Глинистое природное сырьё, применяемое в строительстве с древнейших времен, в последнее время привлекает всё большее внимание инженеров и учёных в связи со всё возрастающими проблемами ресурсо-энергопотребления и экологии. Оно представляет собой глинистые грунты, состоящие из глинистых частиц размерами менее 0,002-0,005 мм, пылевидных частиц от 0,002 до 0,06-0,16 мм и песчаных частиц от 0,06-0,16мм до 2-5 мм. Грунты в связи с этим представляют собой рыхлые мелкозернистые смеси. Грунты - повсеместно распространённый природный материал, глинистые фракции которого не требуют для применения в качестве вяжущего вещества значительных энергетических и трудовых затрат. Глинистые частицы выступают в роли вяжущего для более крупных частиц глинистого грунта. Пылевидная фракция в этих смесях выполняет роль наполнителя, а песчаная фракция - роль мелкого заполнителя. Если содержание глинистых частиц по массе менее $15 \%$, такой грунт называется супесчаным, от 15\% до 30\% - суглинистым, более 30\% - глиной. Если содержание глинистого вещества менее 5\% от общей массы, грунт называется песчаным. 
Глинистые материалы нашли и находят применение в зданиях и сооружениях в виде:

- монолитных глинобетонных стен, перегородок и куполов;

- монолитных элементов слоистых стен и перегородок с облицовкой атмосферо-, водо-, износо-, ударостойкими материалами;

- сырцовых глинобетонных кирпичей и блоков для кладки стен, перегородок, печей и куполов;

- кладочных и штукатурных растворов;

- окрасочных составов.

Глинистые частицы грунтов - самая ранняя в истории человечества разновидность минеральных вяжущих веществ.

\section{Краткая история применения в строительстве глинистого сырья}

Простейшие жилища и укрытия от атмосферных воздействий, построенные в эпоху палеолита с применением глины, на Земле не сохранились. А вот построенные в эпоху неолита можно найти - иногда в полуразрушенном, а иногда даже в сохранившемся состоянии. Древнейшие из обнаруженных жилищ - лёгкие хижины из высушенныхтростников, плетней, обмазанных глиняным раствором. В Туркмении обнаружены дома из грунтовых кирпичей, построенные за 8-6 тысяч лет до нашей эры. В Индии и Месопотамии в IV тысячелетии до н.э. в строительстве отдельных сооружений применялся сырцовый кирпич с кладкой на глиняном растворе. В этот же период

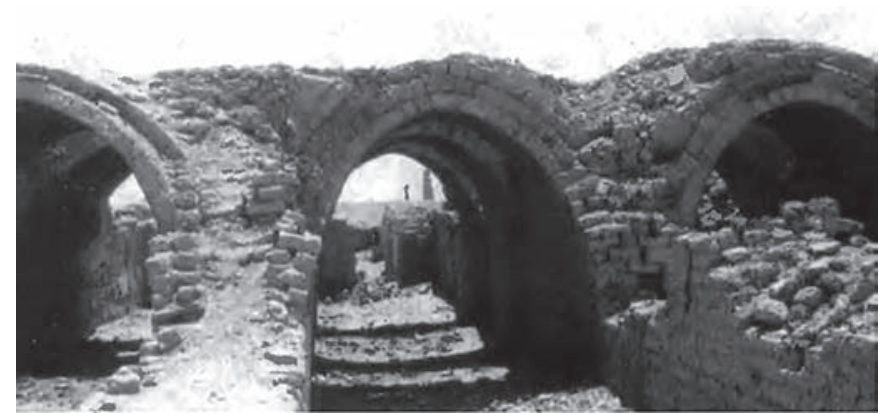

Puc. 1. Своды храма Рамзеса II в Гурне, Ezипет (фото из открытых источников сети Интернет)

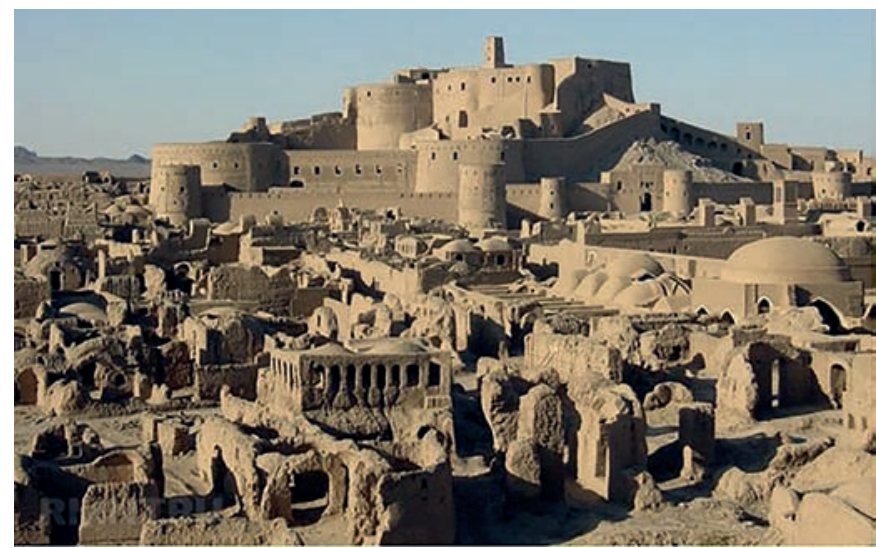

Puс. 2. Крепость Арг-е-Бам (фото из открытых источников сети Интернет) из сырцового кирпича сооружались шахтные гробницы первого фараона Мины и многочисленные мастабы - гробницы царей и знати, в частности, усыпальница фараона Джосера. В каменной и сырцовой кладке использовался глиняный раствор. Во II тысячелетии до н.э. из кирпичей были построены своды храма Рамзеса II в Египте (рис. 1).

Недостатки глины поправляли добавками конского, ослиного и коровьего навозов, соломы и песка.

В Древние века глинобитное строительство и применение глиняных растворов было распространено в Месопотамии, Африке, Испании, Ближнем и Среднем Востоке, о чём упоминается в трудах Плиния Старшего.

B V веке до н.э. в Персии была построена крупнейшая в мире глинобитная крепость Арг-е-Бам (рис. 2).

B V-III веках до н.э. началось строительство Великой Китайской стены из утрамбованной глины, камня и частично обожжённого кирпича. В Индии древняя и наиболее значительная из сохранившихся культовых построек III-I веков до н.э. - большая ступа, воздвигнута из обожжённого кирпича на глиняном растворе. В эпоху Средневековья глинобитное строительство и использование глиняных растворов было развито практически во всех регионах мира, в том числе в Средней Азии, Западной Европе и на территории России. Сохранились остатки землебитных стен, окружавших Бухарский оазис, построенных в X веке. В XII веке первые укрепления на территории современного Московского Кремля были защищены земляным валом шириной около 14,5 и высотой 7 м. Исторический центр Шибам в Йемене, называемый «старейшим городом небоскрёбов в мире» и появившийся в конце I тысячелетия до н.э., состоит в основном из глиняных зданий, около пятисот из которых 5-11-этажные, построены в XVII-XIX веках (рис. 3).

В Германии до сих пор сохранились отдельные многоэтажные глинобитные здания XVI века.

Глинобитное строительство и применение при строительстве из камня, сырцового и обожженного кирпичей, кладочных и штукатурных растворов получили продолжение и в эпоху промышленной революции. В конце XVIII века в Гатчине (сейчас Ленинградская область) архитектором Н.А. Львовым построен землебитный Приоратский дворец (рис. 4).

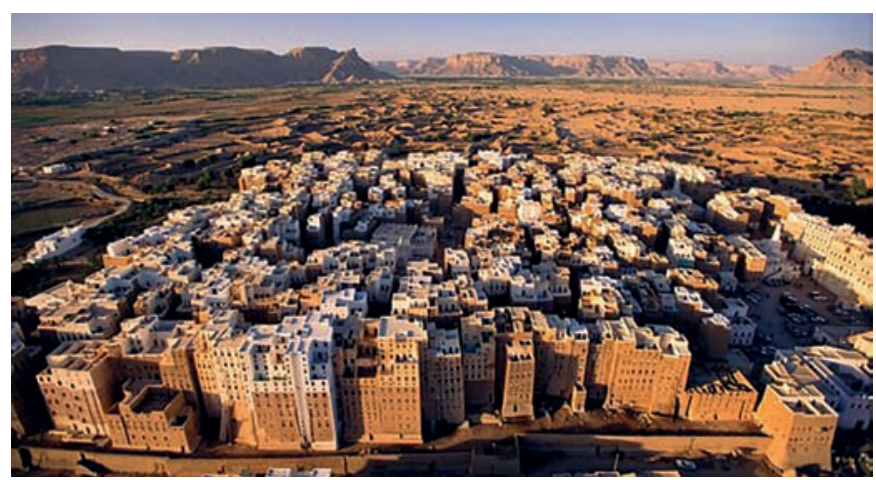

Рис. 3. Город Шибам в Йемене (фото из открытых источников сети Интернет) 
В разных странах Англии и сегодня можно встретить коттеджи, построенные из глины в XVIII-XIX веках и раньше. B XIX веке во всех регионах мира 1-3-6-этажные дома строились глинобитными с применением сырцового кирпича и глиняных растворов. В 1815 году в Сан-Франциско (США) из глинобетона была построена церковь (рис. 5).

Глина - простейшее вяжущее вещество эпохи неолита, до сих пор сохраняет существенное значение для строительства наряду с разнообразными более совершенными вяжущими современности. После Первой и Второй мировых войн в Европе, России и в Средней Азии были построены тысячи глинобитных жилых домов и зданий промышленного и сельскохозяйственного назначения.

По сведениям немецкого учёного Г. Минке даже сейчас треть населения планеты и больше 50\% граждан в развивающихся странах живут в домах, построенных из глиносырцовых материалов. В настоящее время глина используется для строительства жилищ индейцев в Центральной и Северной Америке, Нигерии, странах Ближнего и Среднего Востока, Средней Азии.

Во второй половине и конце XX века с применением сырцового кирпича, тяжёлого и лёгкого глинобетона построены:

- в Германии: жилой дом в Гамбурге и жилой дом в Зигене в 1987 году, два смежных дома с куполообразными крышами в Касселе - в 1985 году, жилой дом с офисом с куполообразными покрытиями всех главных комнат, зимнего сада и центрального холла - в 1992 году (рис. 6) и др.;

- в Бельгии: жилой дом Корбек-Ло со стенами из глинофибробетона и глиняной штукатурки;

- в городе Турку (Финляндия): жилой дом с ограждающими стенами с деревянным каркасом, выложенными из эффективного глиняного кирпича;

- в Йерне (Швейцария): двухэтажное здание антропософической школы с несущими стенами первого этажа из глиносырцовых изделий;

- в Штайн-Рейне (Швейцария): трёхэтажный дом с внутренней стороной наружных стен из глинодеревобетонных блоков, отштукатуренных глиняным раствором, и внутренними стенами из сырцового кирпича (рис. 7);

- в Калининграде (Россия): детский дом общей площадью 264 кв. м с наружными стенами из соломенных блоков, отштукатуренных глиняным раствором, и внутренними стенами из сырцового кирпича.

В конце XX века в Австралии несколько фирм построили с использованием глинобетона сотни зданий, в числе которых отель и церковь (фирма «Рамтек»). В это же время строительство таких зданий вели в фирмы «Хульс», «Ларовек», «Тераформ» (Германия); фирма «Глинобетонные работы» (США).

Показатели свойств материалов из глинистого сырья могут быть улучшены за счёт регулирования и установления оптимального соотношения содержания в них глин, пылевидных и песчаных фракций. Прочность глинобетона в сухом состоянии может колебаться в пределах от 0,5 до 5,0 МПа, Но

при этом показатели его при растяжении и изгибе меняются незначительно.

\section{Недостатки и достоинства глинистых вяжущих и материалов на их основе \\ Недостатки:}

- низкая водостойкость, атмосферостойкость, стойкость в растворах солей, кислот и щелочей;

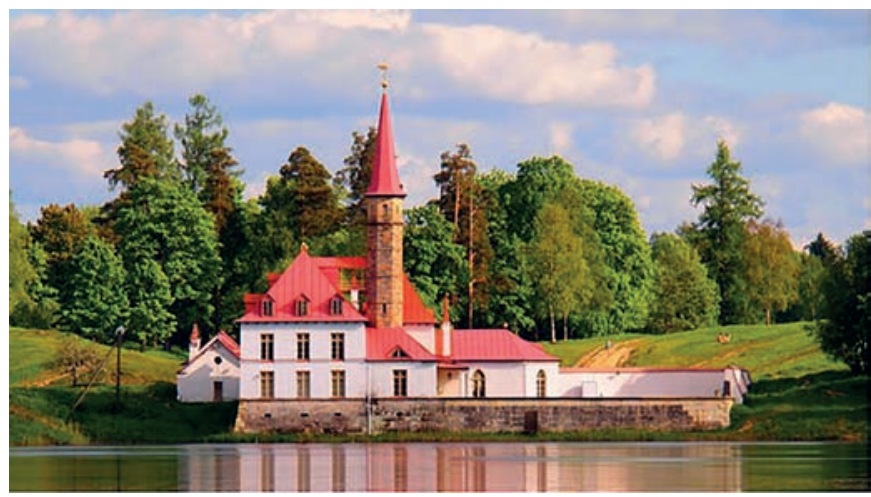

Рис. 4. Приоратский дворец, с землебитными стенами (фото из открытых источников сети Интернет)

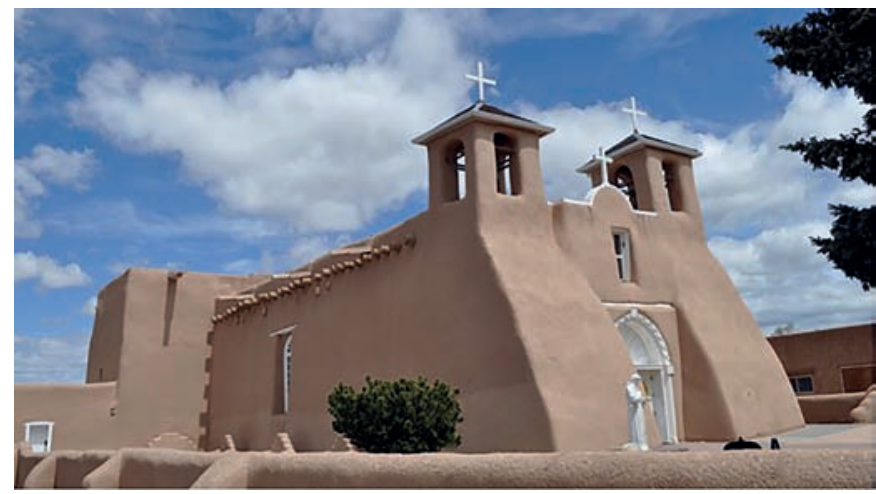

Рис. 5. Церковь из глинобетона. Сан-Франциско, США (фото из открытых источников сети Интернет)

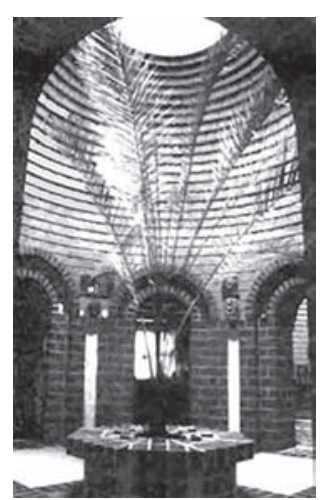

Рис. 6. Центральный холл с куполом жилого дома софисом. Кассель, Германия (фото из открытых источников сети Интернет)

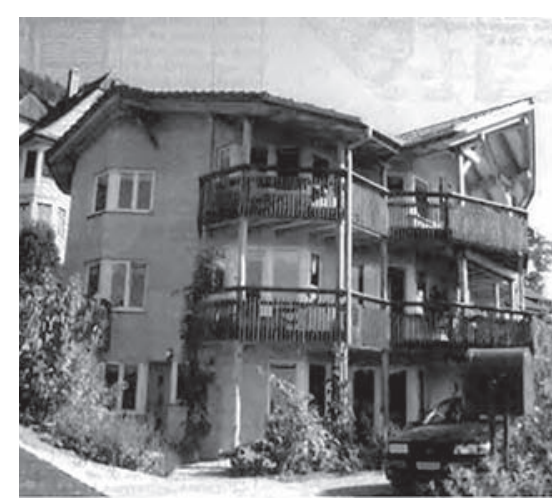

Рис. 7. Дом в Швейцарии на три семьи (фото из открытых источников сети Интернет) 
- низкие показатели физико-механических свойств прочности, истираемости и др.;

- неоднородность глинистых грунтов;

- значительные усадочные деформации и трещинообразование при сушке.

Достоинства:

- стоимость и трудоёмкость производства и применения почти в десять раз ниже по сравнению с другими вяжущими и материалами на их основе;

- энергоёмкость производства по сравнению с другими вяжущими и материалами на их основе ниже почти в сто раз;

- уровень загрязнения окружающей среды ничтожен по сравнению с производством и применением других вяжущих и материалов на их основе;

- применение таких вяжущих обеспечивает рациональное использование природных ресурсов, создаёт благоприятный климат в помещениях, уравновешивая в них влажность воздуха;

- такие вяжущие поглощают загрязняющие вещества в воздухе и воде;

- могут использоваться повторно.

\section{Добавки, регулирующие свойства материалов на основе глинистых вяжущих}

Добавки к глинобетону монолитных конструкций, кирпичей и блоков в зависимости от минерального состава:

- повышающие прочность при сжатии: портландцемент, известь, портландцемент + известь, цемянка, льняное масло, целлюлоза, крахмал, молочная сыворотка, жидкое стекло с кварцевым песком и мелом; портландцемент и известь с добавками пуццоланов - зола-унос, вулканический пепел, зола рисовой шелухи и др.; урина и ацетат аммония;

- понижающиеусадку и повышающие трещиностойкость, прочность при растяжении и изгибе: минеральные и синтетические волокна, резаная солома, кокосовое волокно, иглы хвойныхдеревьев, урина с ацетатом аммония, льняное масло, целлюлоза, крахмал, алоэ, бамбук, волос животных, молочная сыворотка, обезжиренный творог, навоз, свежий сыр, известково-казеиновый клей;

- повышающие прочность на истирание: водный раствор жидкого стекла, льняная олифа 5\%, смесь 5-процентного обезжиренного творога и 5-процентной извести;

- пластифицирующие: жидкое стекло, сода, гумусовые и дубильные кислоты;

- ускорители твердения цементогрунтов: сульфат, карбонат и силикат натрия - примерно 10\% на каждый литр воды затворения;

- для повышения водо- и атмосферостойкости: цемент, известь, битум с органическими растворителями или водными эмульсиями, водный раствор жидкого стекла, кровь, урина, навоз, казеин, костный клей, известь с навозной жижей или с обезжиренным творогом, масло- и латекс-содержащие млечные соки каучуковых растений, синтетические смолы, парафины, латексы, искусственный воск, силен, силоксан, эфиры кремниевой кислоты;
- для понижения теплопроводности: резаная солома, морская трава, тростник, пробка, пемза, керамзит, пеностекло, вулканический туф, вспученный перлит, древесные опилки, стружка, щепа, пено- и газообразователи.

Добавки для глиняной штукатурки в зависимости от наружного или внутреннего расположения и атмосферных условий:

- казеиновый клей с добавлением извести, обезжиренный творог, борная кислота, урина, глюконат натрия, целлюлоза - повышают сопротивление истиранию и мелению; добавка урины в раствор на основе глинистого грунта с большим содержанием пылевидных частиц повышает его прочность на сжатие и изгиб; добавка целлюлозы в глиняный раствор повышает его трещиностойкость;

- волокнистые добавки - для уменьшения трещинообразования;

- цемент, известь, казеин и др. - для увеличения прочности при механических воздействиях, водостойкости и сопротивления истиранию;

- керамзит, пемза, туф, древесные опилки, соломенная и льняная сечка, пеностекло - для теплоизоляционной штукатурки.

Окрасочные составы глинобетонных конструкций и глиняной штукатурки с глиняными порошками:

- известь + поваренная соль + цветной глиняный порошок;

- известь + обезжиренный творог + глиняный порошок;

- казеин + борная кислота + меловой и глиняный порошок;

- каолиновая глина + урина + ацетат аммония.

Составы, имеющие небольшое содержание глинистых частиц, очень хорошо держатся на глиняной штукатурке с шероховатой поверхностью.

Кроме отмеченных окрасочных составов рекомендуются для защиты глинобетонных поверхностей составы:

- известковые, известково-казеиновые, казеиновые краски;

- известковая паста из молотой негашёной извести с растопленным животным жиром и водой;

- гидравлическая известь с уриной;

- известковая краска с животным клеем, водой и гидравлической известью;

- клеевые краски на основе карбоксиметилцеллюлозы и других полимеров и мела;

- битумные лаки.

\section{К повышению эффективности грунтов}

Материалы, получаемые при высушивании бездобавочных пластических масс глинистых грунтов, имеют предел прочности при сжатии 1,0-5,0 МПа в зависимости от минерального и гранулометрического составов и содержания и разновидностей примесей.

Во второй половине XX века выполнялись исследования в направлении значительного - до 10 и более раз - повышения физико-технических свойств, содержащих глинистые минералы в основных или значительных объёмах: 
- в СССР Киевской научной школой Глуховского В.Д. были разработаны грунтосиликатные вяжущие на основе глин и соединений щелочных металлов с прочностью при сжатии до 30 МПа и более;

- в последнее десятилетие в России Пензенской научной школой Калашникова В.И. разработаны научные основы и технология получения глиношлаковых строительных материалов с содержанием 40-60\% глины и механохимически активированных металлургических шлаков с добавками лигносульфоната и щелочей.

Перспективы строительства с монолитными и сборными конструкциями и изделиями из глинобетона

За прошедшие двадцать лет XXI века численность населения Земли возросла более чем на полтора миллиарда и насчитывает более 7,7 миллиарда, что позволяет предположить дальнейший её рост и в будущем. Это естественно потребует и соответствующий рост объёмов жилищного и культурно-бытового строительства, производства и потребления строительных материалов. Этап формирования мирового хозяйства конца XIX - начало XXI века характеризуется возросшей необходимостью освоения географического пространства (особенно актуально для России), ростом промышленной и сельскохозяйственной сфер производства. Это будет сопровождаться увеличением роста потребления топливных ресурсов - жидких (включая нефть), твёрдых и газа, - которое за последние двадцать лет увеличилось почти на 50\%. При этом возрастала и эмиссия углекислого газа в атмосферу - ежегодно на 0,5-0,7\%, что со временем может привести к экологическому мировому коллапсу.

В связи со всем вышеотмеченным глинобетонное строительство, развитие и расширение которого в последние десятилетия уже отмечается в некоторых регионах Австралии и США, является перспективным и в других регионах мира, в том числе и в России, учитывая его низкую энерго- и трудоёмкость, а также экологическую безвредность по сравнению с применением строительных материалов, получаемых по высоким трудо-, энерго-, металлоёмкими и экологически нечистым технологиям.

Известные разработки грунтосиликатных и глиношлаковых материалов свидетельствуют о целесообразности дальнейших изысканий в части получения высокопрочных материалов на основе грунтов.

Развитие и расширение монолитного и сборного глинобитного строительства является эффективным при строительстве:

- одно- двухэтажных жилых, культурно-бытовых, сельскохозяйственных и промышленных зданий в малонаселённых и удалённых от промышленно развитых регионов районах;

- в пригородных зонах - одно- двухэтажных коттеджей, домов, зданий бытового и сельскохозяйственного назначения;

- многоэтажных каркасных зданий с самонесущими стенами из штучных безобжиговых изделий из тяжёлого и лёгкого глинобетонов;

- зданий и сооружений небольшими частными фирмами.

\section{Лumepamypa}

1. Грим, Р.С. Минералогия глин / Р.С. Грим; Пер. с англ. - М. : Изд-во иностр. литер., 1959. - 452 с.

2. Петров, В.П. Глины, их минералогия, свойства и практическое применение / В.П. Петров. - М. : Госстройиздат, 1970.

3. Глинобитные постройки // Техническая энциклопедия. T.5. - М. : Советская энциклопедия, 1929. - С. 658-661.

4. Технология строительства глинобитного дома [Электронный ресурс] // СтройРубрика.Ру. - Режим доступа: https://stroyrubrika.ru (дата обращения 10.02.2021).

5. Ильина, Е.А. Строим загородный дом : Полное руководство для современного застройщика / Е.А. Ильина, М.П. Мартемьянов, Б.С. Омурзуков. - М. : Эксмо, 2020. - 320 с.

6. Ефремов, Г. Саманный кирпич - доступный строительный материал / Г. Ефремов // Сделай сам : альманах. - М. : Огонёк, 2001. -№ 2. - С. 3-21.

7. Минке, Г. Глинобетон и его применение / Г. Минке. Калининград : Янтарный сказ, 2004. - 232 с.

8. Nemeyer, $R$. Der Lehmbau and seure praktische Auwendung / R. Nemeyer. - Hamburg, 1946.

9. Guntzel, J.G. Zar Geschichte der Lehmbaues in Deutschland / J.G. Guntzel Kassel : Gesamthoch schule Kassel, 1988.

10. Попов, H.A. Технические указания по производству и применению грунтобетонов для массового строительства / Попов Н.А., Богин Н.М. - М. : Издательство Акад.архитектуры СССР, 1945.

11. Рузин, Б.В. Строительство из глиносырцовых материалов / Б.В. Рузин. - М. : Госстройиздат, 1956.

12. Глуховский, В.Д. Грунтосиликаты / В.Д. Глуховский. Киев, Госстройиздат, 1959.

13. Глиношлаковые строительные материалы / В.И.Калашников, В.Ю. Нестеров, В.Л. Хвастунов [и др.]; Под общ. ред. В.И.Калашникова. - Пенза : ПГАСА, 2000.

\section{References}

1. Grim R.S. Mineralogiya glin [Mineralogy of Clays], Trans. from Engl. Moscow, Publishing house foreign literature, 1959, 452 p. (In Russ.)

2. Petrov V.P. Gliny, ikh mineralogiya, svoistva i prakticheskoe primenenie [Clays, their mineralogy, properties and practical application]. Moscow, Gosstroiizdat Publ., 1970. (In Russ.)

3. Glinobitnye postroiki [Earthen buildings]. In: Tekhnicheskaya entsiklopediya [Technical encyclopedia], Vol. 5. Moscow, Soviet encyclopedia Publ., 1929, pp. 658-661. (In Russ.)

4. Tekhnologiya stroitel'stva glinobitnogo doma [Technology of building an adobe house]. StroyRubrika.Ru. Access mode: https://stroyrubrika.ru (Accessed 02/10/2021). (In Russ.)

5. Il'ina E.A., Martem'yanov M.P., Omurzukov B.S. Stroim zagorodnyi dom. Polnoe rukovodstvo dlya sovremennogo zastroishchika [We are building a country house. A complete guide for a modern developer]. Moscow, Eksmo Publ., 2020, 320 p. (In Russ.)

6. Efremov G. Samannyi kirpich - dostupnyi stroitel'nyi material [Adobe brick - an affordable building material]. In: 
"Sdelai sam" ["Do it yourself"], almanac. Moscow, Ogonek Publ., 2001, no. № 2, pp. 3-21. (In Russ.)

7. Minke G. Glinobeton i ego primenenie [Clay concrete and its application]. Kaliningrad, Yantarnyi skaz Publ., 2004, 232 p. (In Russ.)

8. Nemeyer R. Der Lehmbau and seure praktische Auwendung. Hamburg, 1946. (In Germ.)

9. Guntzel J.G. Zar Geschichte der Lehmbaues in Deutschland. Kassel, Gesamthoch schule Kassel Publ., 1988. (In Germ.)

10. Popov N.A., Bogin N.M. Tekhnicheskie ukazaniya po proizvodstvu i primeneniyu gruntobetonov dlya massovogo stroitel'stva [Technical instructions for the production and use of soil concrete for mass construction]. Moscow, Publishing house of the Academy of Architecture of the USSR, 1945. (In Russ.)

11. Ruzin B.V. Stroitel'stvo iz glinosyrtsovykh materialov [Construction of clay-raw materials]. Moscow, Gosstroiizdat Publ., 1956. (In Russ.)

12. Glukhovskii V.D. Gruntosilikaty [Soil silicates]. Kiev, Gosstroiizdat Publ., 1959. (In Russ.)

13. Kalashnikov V.I. Nesterov, V.Yu., Khvastunov V.L. [et al.]. Glinoshlakovye stroitel'nye materialy [Clay-slag building materials], V.I. Kalashnikova (ed.). Penza, PGASA Publ., 2000. (In Russ.)

Рахимов Равиль Зуфарович (Казань). Доктор технических наук, профессор, член-корреспондент РААСН. Профессор кафедры строительных материалов ФГБОУ В0 «Казанский государственный архитектурно-строительный университет (420043, Республика Татарстан, Казань, ул. Зеленая, 1. КазГАСУ).

Рахимова Наиля Равильевна (Казань). Доктор технических наук, профессор. Профессор кафедры строительных материалов ФГБОУ В0 «Казанский государственный архитектурно-строительный университет (420043, Республика Татарстан, Казань, ул. Зелёная, 1. КазГАСУ). Эл. почта: rahimova.07@list.ru.

Rakhimov Ravil Z. (Kazan). Doctor of Technical Sciences, Professor, Corresponding Member of RAACS. Professor of the Department of Building Materials at the Kazan State University of Architecture and Engineering (1 Zelenaya St, Kazan, 420043. KSUAE).

Rakhimova Nailya R. (Kazan). Doctor of Technical Sciences, Professor. Professor of the Department of Building Materials at the Kazan State University of Architecture and Engineering (1 Zelenaya St., Kazan, 420043. KSUAE). E-mail: rahimova.07@list. 


\section{Запечатлённая архитектурная история России}

5 января 2021 года знаменательный юбилей отметила Евгения Ивановна Кириченко, академик РААСН, доктор искусствоведения, заслуженный деятель искусства, лауреат Государственной премии РФ, главный научный сотрудник РАХ.

Человек непоколебимой научной смелости и титанического трудолюбия, она неустанно прокладывает новые пути развития фундаментальных знаний в области теории и истории архитектуры. Ее труды внесли неоценимый вклад в освоение национального историко-культурного наследия и стали прочным основанием для изучения, сохранения и продолжения традиций градостроительного искусства и архитектуры России.

От души поздравляем и желаем Евгении Ивановне крепкого здоровья, новых книг и открытий, творческого долголетия!
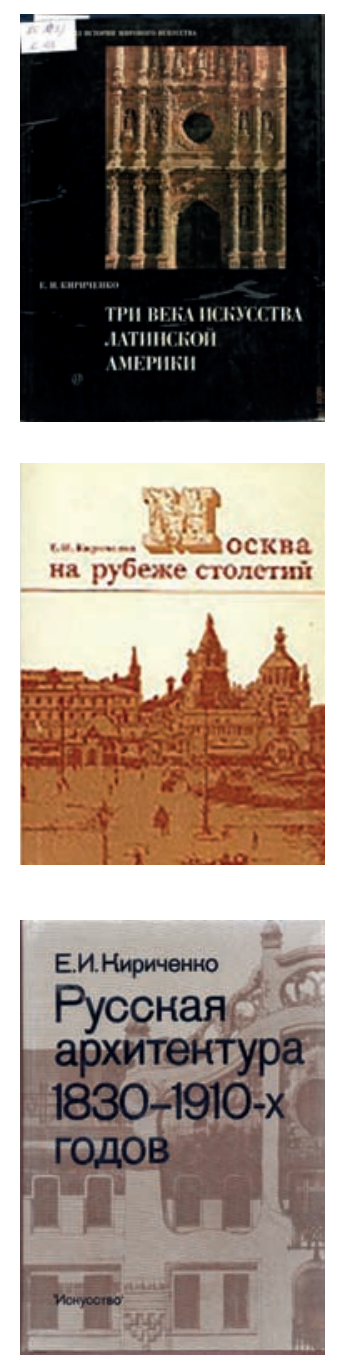

Три века искусства Латинской Америки. Конец XV - первая четверть XIX в. - М. : Искусство, 1972. - 143 с., 81 л. ил.

Искусство XV - первой четверти XIX века - одна из трёх великих эпох художественного развития Латинской Америки. Оно занимает срединное положение, связывая самобытные цивилизации Древней Америки с культурой нового времени. Издание содержит огромное количество фотоиллюстраций.

Москва на рубеже столетий. - М. : Стройиздат, 1977. - 183 с. : ил.

Книга посвящена зодчеству Москвы второй половины XIX - начала XX в. Рассказывается об основных этапах развития архитектуры этого периода; характеризуются события архитектурной жизни, наиболее типичные архитектурные направления; дается анализ основных памятников. Большое внимание уделяется исследованию городского организма, тенденциями его трансформации и специфическим особенностям в этапные моменты развития.

Русская архитектура 1830-1910-х годов. - М. : Искусство, 1978. - 399 с., ил.

В первой части книги говорится о русской архитектуре 1830-1890-х гг. или в соответствии с принятой в отечественном искусствознании терминологией - об эклектике. На ее материале сделана попытка осветить три круга вопросов, рассматриваемых затем и во второй части. В первой главе анализируется композиционная система, во второй - система основных представлений и идей, воплощаемых в зодчестве и моделируемых им в качестве наиболее существенных с точки зрения миропонимания времени, в третьей - реализация композиционной и содержательной систем в реальной практике, архитектурные направления и наиболее яркие их представители (в их числе - М. Д. Быковский, К.А. Тон, А.И. Штакеншнейдер, А.М. Горностаев, В.А. Гартман, И.П. Ропет, Н.В. Султанов и другие).

Вторая часть книги посвящена анализу русской архитектуры конца XIX - начала XX в. Проблематика и круг затрагиваемых проблем те же, что и в первой части. Рассматривается композиционная система, своего рода идеальная модель архитектуры тех лет, идейно-художественное содержание, ею выражаемое, архитектурные направления и их крупнейшие представители. Речь идет по преимуществу о модерне; а в последней, третьей главе, - о модерне и ретроспективизме, их важнейших разновидностях и выдающихся мастерах: Ф.О. Шехтеле, Л.Н. Кекушеве, Н.В. Васильеве, И.С. Кузнецове, И.Е. Бондаренко, В.М. Васнецове, Е.Д. Поленовой, С.В. Малютине, В.А. Покровском, И.А. Фомине и других. 

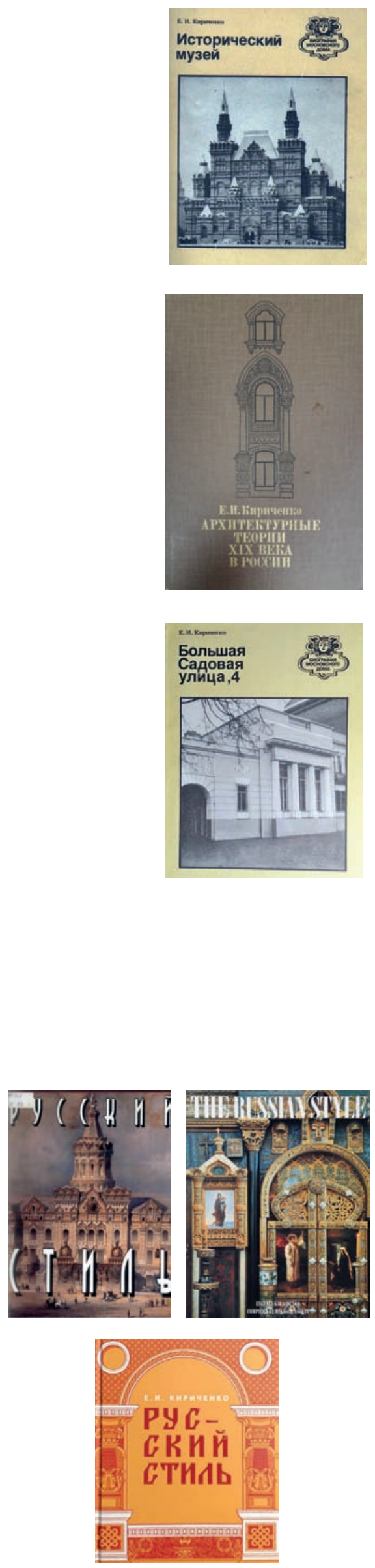

Исторический музей : К 100-летию открытия Гос. ордена Ленина исторического музея : [путеводитель] - М. : Московский рабочий, 1984. - 64 с., 8 л. ил.

Государственный Исторический музей - богатейшее хранилище исторических ценностей, дающих представление о развитии отечественной истории и истории народов Советского Союза, один из культурно-просветительных и научных центров Москвы. Книга знакомит с историей создания музея, строительством предназначавшегося для него здания и историей застройки участка, на котором находится это сооружение

Архитектурные теории XIX века в России. - М. : Искусство, 1986. - 344 С., ил.

В книге рассматриваются архитектурные теории в России XIX в., точнее, 1830-1890-х гг. В двух частях книги, посвящённых соответственно второй трети и второй половине XIX в., охарактеризованы взгляды на архитектуру не только профессиональных зодчих, но и крупнейших русских литераторов, философов, мыслителей - Н. Гоголя, Н. Надеждина, П. Чаадаева. В. Одоевского, А. Герцена, славянофилов, Н. Чернышевского, Ф. Достоевского. Архитектурные теории в книге предстают как часть культурфилософских, историософских, культурологических, а подчас и социально-политических концепций, свойственных русской общественной мысли прошлого столетия.

Большая Садовая улица, 4. - М. : Московский рабочий, 1989. - 79 с.; ил. ISBN 5-239-00693-8

На одной из самых оживленных магистралей столицы - Садовом кольце, близ площади Маяковского, стоит небольшой дом. В окружении расположенных поблизости многоэтажных громад он кажется особенно хрупким. Его главный, выходящий на Большую Садовую фасад, украшенный торжественным портиком из четырёх колонн дорического ордера, обнаруживает некоторое сходство с особняками начала прошлого столетия. Однако дом сравнительно молод. Его построил выдающийся архитектор Ф.0. Шехтель.Книга знакомит с одним из примечательных эданий Москвы - домом, сооруженным крупным зодчим конца XIX - начала XX века Федором Осиповичем Шехтелем. Выдающийся памятник архитектуры принадлежит к своеобразной разновидности жилых домов, построенных архитекторами для себя. Рассказывается также о других домах, которые построил в Москве Шехтель, а также о замечательных людях, с которыми связана история дома на Большой Садовой, членах семьи Шехтеля, о военачальнике Р.П. Эйдемане и скульпторе И.Д. Шадре.

Русский стиль : поиски выражения национальной самобытности. Народность и национальность. Традиции древнерусского и народного искусства в русском искусстве XVIII-начала XX века. - М. : Галарт, 1997. - 430 с. : ил., цв. Ил.

Кириченко Е.И. Русский стиль. Поиски выражения национальной самобытности. Народность и национальность. Традиции древнерусского и народного искусства в русском искусстве XVIII - начала XX век. - 2-е изд., испр. и доп. - М. : БуксМАрт, 2020. - 580 с. : ил..

Спустя более чем два десятилетия вышла в свет в новой авторской редакции широко известная в России и за рубежом уникальная монография Е.И. Кириченко «Русский стиль», посвящённая становлению и развитию одноименного стилевого направления в градостроительстве, архитектуре, живописи и прикладном искусстве XVIII-XX веков. Второе издание включает переработанный и расширенный иллюстративный ряд и более поздние статьи автора, касающиеся теоретических вопросов и рассматривающие отдельные произведения и целые архитектурные ансамбли, в которых воплотились формы и приёмы древнерусского зодчества и народного искусства. 